\title{
Some effects of a white grub infestation on northern mixed-grass prairie
}

\author{
CHARLES L. LURA AND PAUL E. NYREN
}

\begin{abstract}
Authors are associate range scientist, Department of Animal and Range Science, North Dakota State University, Fargo 58105; and superintendent/range scientist, Central Grasslands Research Center, Streeter, N.D. 58483.
\end{abstract}

\begin{abstract}
Graminoid standing crop in June 1985 on areas infested with white grubs (Phyllophaga anxia LeConte) (average density $=47$ grubs $\mathrm{m}^{-2}$ ) was $92 \%$ less than on uninfested rangeland (average density $<2$ grubs $\mathbf{m}^{-2}$ ). Study area was the Central Grasslands Research Center in south-central North Dakota. Infestations were noticeably associated with communities dominated by western snowberry (Symphoricarpos occidentalis Hook.) with an understory subdominance of Kentucky bluegrass (Poa pratensis L.). The objective of our study was to assess the initial impact and subsequent recovery of infestation on community standing crops and plant densities. Mid and late summer standing crops of Kentucky bluegrass and other grasses were significantly less $(P<0.05)$ on infested than uninfested sites between 1985 and 1987. Graminoid density was less $(P<0.05)$ on infested than uninfested sites during 1985 and 1986. Post-infested standing crop and density of forbs increased $(P<0.05)$ on infested sites. Infestation of sites subsequently provided habitat for establishment of noxious weeds such as wormwood sage (Artemisia absinthium L.). Management techniques to enhance the recovery of grasses and eliminate establishment of noxious weeds may be necessary.
\end{abstract}

Key Words: Phyllophaga anxia, Scarabaeidae, retroǵression, succession

During the spring of 1985 , extensive areas resulting from an infestation of white grubs (Phyllophaga anxia LeConte) (Coleoptera: Scarabaeidae) were noted on the North Dakota State University Central Grasslands Research Center. Infestations occurred on about $12 \%$ of the native range on the study area, and were associated with western snowberry (Symphoricarpos occidentalis Hook.) communities which occupy approximately $33 \%$ of the native plant communities on the area (Lura 1985). Kentucky bluegrass (Poa pratensis L.) is the major graminoid associate of these communities and may account for up to $70 \%$ of the total graminoid production (Kirby et al. 1988).

White grubs are larvae of June beetles, which are among the most destructive soil insects on grasslands (Hewitt et al. 1974). Most species of white grubs have a 3-year life cycle in which the larvae spend most of $\mathbf{3}$ growing seasons feeding on the roots of grasses (Anon. 1959). A complete review of the life cycle of the Scarabaeidae is given in Richter (1958).

Although white grubs are known to affect large areas of rangeland (Hewitt et al. 1974), quantitative information on infestations is scarce. Ueckert (1979) reported on a white grub infestation in Texas in which most plant species had recovered (foliar cover) by the end of the second growing season. Efforts to control white

\footnotetext{
The authors thank D.K. McBride, North Dakota State Extension entomologist for taxonomic determination of insect specimens.

Support provided by North Dakota State University Agricultural Experiment Station, Project ND06141.

Journal Article 1939 of the North Dakota Agricultural Experiment Station.

Manuscript accepted 17 September 1991.
}

grubs and speed vegetative recovery through various combinations of insecticide, fertilizer, and reseeding treatments were not considered successful. The objectives of our study were to assess the impact of infestations on above-ground biomass and species composition of affected communities and to monitor recovery.

\section{Study Area}

The study area lies within the northern mixed-grass prairie (Kuchler 1964). Characteristic soils of the study area are fineloamy, mixed Typic Argiborolls and fine-loamy, mixed Typic Haploborolls. Mean annual precipitation is $441 \mathrm{~mm}$. Annual precipitation for 1985 through 1988 was $454,674,417$, and $213 \mathrm{~mm}$, respectively.

Before 1979 the area was grazed seasonally or season-long by livestock at moderate to heavy stocking rates: exact grazing history, however, is unknown. The portion of the area in which sampling occurred was largely idle from 1980 through 1985 with occasional light grazing by cattle during fall.

\section{Methods}

During June 1985, 20 pairs of permanent sites were subjectively located within white grub infested areas and adjacent uninfested areas of similar soils and plant species composition approximating vegetation on infested areas prior to infestation. Within each site, vegetation in 1 randomly located $50 \times 50-\mathrm{cm}$ quadrat was clipped at ground level during mid June and mid September of 1985. Vegetation was sampled only during mid September in 1986 and 1987.

Samples were sorted, oven-dried at $55^{\circ} \mathrm{C}$, and weighed to the nearest $0.1 \mathrm{~g}$. Six pairs of permanent transects were chosen for detailed analysis of species composition during 1985-1988. For each transect, twenty $31.6 \times 31.6-\mathrm{cm}$ quadrats were used to determine forb and shrub densities. Graminoid densities were determined within nested $10.0 \times 10.0$-cm quadrats. White grub densities were determined in mid June 1985-1988 by excavating the upper $7.6 \mathrm{~cm}$ of the soil profile in 1 randomly located $50 \times 50-\mathrm{cm}$ quadrat on each site. Study sites were protected from grazing by domestic livestock for the duration of the study. A standard $t$-test was used to determine differences between infested and uninfested areas $(\mathrm{P}<0.05)$.

\section{Results and Discussion}

\section{White Grub Infestation}

White grub density averaged $47 \mathrm{~m}^{-2}$ in the 0 to $7.6-\mathrm{cm}$ soil layer on infested sites in 1985 (Table 1). Ueckert (1979) reported 43.6 white grubs $\mathrm{m}^{-2}$ to a depth of $20 \mathrm{~cm}$. White grubs were not encountered in 1986, but adults were observed. During 1987, white grubs were encountered in both infested and uninfested sites. The white grubs in 1987 were assumed to be from eggs laid during 1986. If so, only 1 brood was inhabiting the area. Greater numbers of white 
Table 1. Mean white grub densities $\left(m^{-2}\right.$ to $7.6-\mathrm{cm}$ depth) and graminoid densities $\left(\mathrm{m}^{-2}\right) \pm$ standard error of means on white grub infested and uninfested sites on the Central Grasslands Research Center, 1985-1988.

\begin{tabular}{|c|c|c|c|}
\hline Year & Location & White grubs & Graminoids \\
\hline \multirow{2}{*}{1985} & Infested & $47.0 \pm 4.8$ & $283 \pm 103$ \\
\hline & $\begin{array}{l}\text { Uninfested } \\
\text { Infested }\end{array}$ & $\begin{array}{l}1.6 \pm 1.6^{* *} \\
0.0\end{array}$ & $\begin{array}{l}3346 \pm 189 * \\
1348 \pm 355\end{array}$ \\
\hline 1986 & $\begin{array}{l}\text { Uninfested } \\
\text { Infested }\end{array}$ & $\begin{array}{l}0.0 \\
38.6 \pm 10.4\end{array}$ & $\begin{array}{l}3819 \pm 359 * \\
1907 \pm 234\end{array}$ \\
\hline 1987 & $\begin{array}{l}\text { Uninfested } \\
\text { Infested }\end{array}$ & $\begin{aligned} & 14.8 \pm 5.0^{*} \\
& 4.8 \pm 2.0\end{aligned}$ & $\begin{array}{l}2523 \pm 171 \\
1345 \pm 197\end{array}$ \\
\hline 1988 & Uninfested & $3.4 \pm 1.8$ & $1397 \pm 132$ \\
\hline
\end{tabular}

*,**Infested differs from uninfested $p<0.05$ and $p<0.001$ respectively.

grubs $(P<0.05)$ were encountered in infested sites than uninfested sites in 1987. June beetles are known to be weak fliers, thus we hypothesize that females oviposited in close proximity to where they emerged as adults. Few white grubs were found in 1988, and there was no noticeable damage to vegetation.

Injury to Kentucky bluegrass pastures has been shown to increase when plants are under stress, such as low soil fertility, low soil moisture, or lowered carbohydrate reserves as might result from over-grazing (Graber et al. 1931). We do not believe vegetation was unduly stressed at the onset of this infestation. Infestation effects appeared similar on idle as well as grazed areas. Additionally, the precipitation received was near average, and soil nutrients, nitrogen, phosphorus, and organic matter on the study area did not indicate any deficiencies (Lura 1985).

\section{Aboveground Biomass}

Aboveground biomass on infested sites in June 1985 was $25 \%$ of that on uninfested sites (Fig. 1). Graminoid standing crop was reduced on infested sites by $92 \%$. Standing crops of Kentucky bluegrass, other grasses, sedges (Carex spp.), and total standing crop were less $(P<0.05)$ on infested sites. Standing crop of graminoids remained less $(P<0.05)$ on infested sites in September; but that of forbs increased $(P<0.05)$ on infested sites. This resulted in no difference in total standing crop between infested and unin- fested sites. Forbs contributed $82 \%(1,836 \mathrm{~kg} / \mathrm{ha})$ of the total standing crop on infested sites and $6 \%(142 \mathrm{~kg} / \mathrm{ha})$ on uninfested sites. No differences $(P<0.05)$ were found for western snowberry biomass.

Standing crop of Kentucky bluegrass and other grasses remained less $(P<0.05)$ on infested sites during 1986 . Graminoid standing crop on infested sites was $13 \%$ of that on uninfested sites. Forbs remained more productive $(P<0.05)$ on infested sites and accounted for $82 \%$ of the total standing crop. Total standing crop was less $(P<0.05)$ on infested sites. The larger standing crop in 1986 is largely due to increased precipitation, as April through July precipitation was $168 \%$ of average.

Total standing crop was not different $(P<0.05)$ between infested and uninfested sites by the end of the second growing season following infestations (1987). All standing crops of graminoids were, however, less $(P<0.05)$ on infested sites. Graminoid standing crop increased by $422 \mathrm{~kg} / \mathrm{ha}$ on infested sites compared to 1986, though precipitation was less. Graminoid standing crop on infested sites was $33 \%$ of that on uninfested sites. Sedge standing crop was different $(P<0.05)$ between infested and uninfested sites in 1987 whereas in 1986 it was not. This may be due to variations in amount and distribution of precipitation. Biomass on infested sites remained dominated by forbs. Forb standing crop remained greater $(P<0.05)$ on infested sites and accounted for $71 \%$ of the total.

\section{Plant Density}

Total graminoid density between infested and uninfested sites was different $(P<0.05)$ during 1985 and 1986 (Table 1). The reduced density in 1988 was attributed to drought. Significant reductions in graminoid density on infested sites during 1985 occurred for western wheatgrass (Agropyron smithii Rydb.), blue grama (Bouteloua gracilis (H.B.K.) Lag. ex Griffiths), needleleaf sedge (Carex eleocharis Bailey), sun sedge (Carex heliophila Mack.), prairie junegrass (Koeleria pyramidata (Lam.) Beauv.), Kentucky bluegrass and needleandthread (Stipa comata Trin. \& Rupr.). By 1987, only densities of western wheatgrass and needleleaf sedge were reduced $(P<0.05)$ on infested sites. Although graminoid densities were similar on infested and uninfested sites after 1986, graminoid standing crop remained less $(P<0.05)$ on infested sites (Fig. 1).

Forbs increased markedly on infested sites. Densities increased

\section{Uninfested}

$\mathrm{Kg} / \mathrm{Ha}$

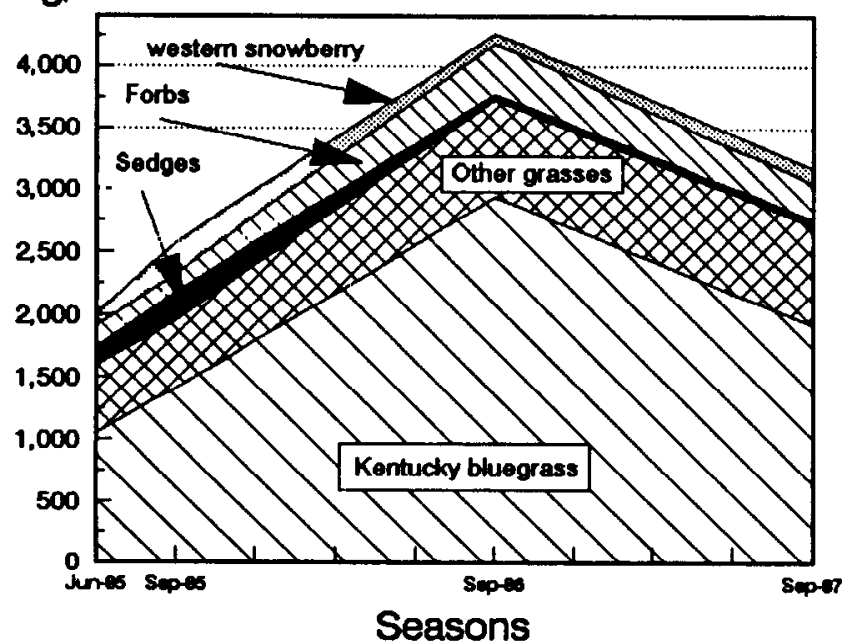

\section{Infested}

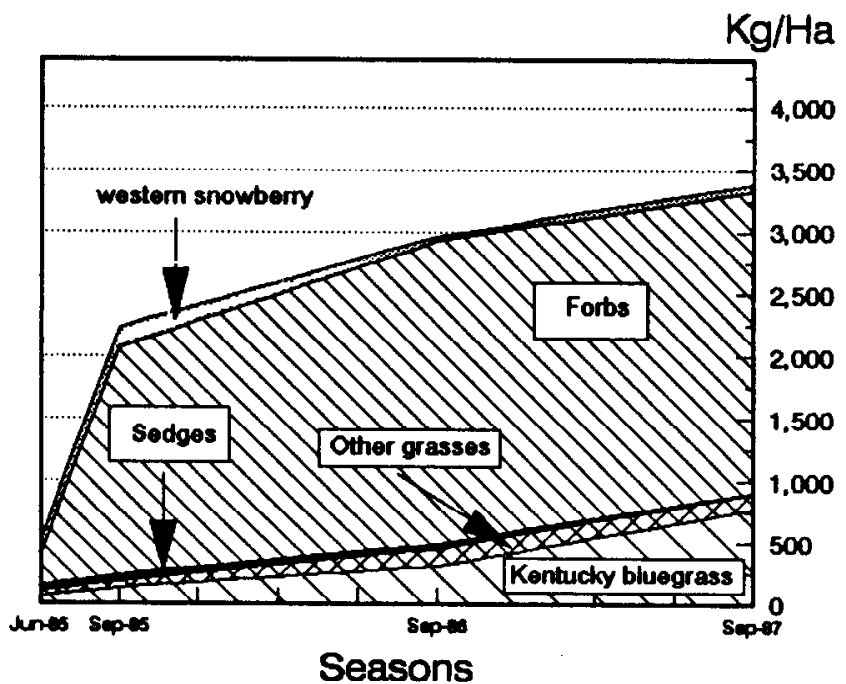

Fig. 1. Standing crops on white grub infested and uninfested sites on the Central Grasslands Research Center $1985-1987$. 
on infested sites in 1985 for goosefoot (Chenopodium leptophyllum Nutt. ex Moq.), horseweed (Conyza canadensis (L.) Cronq.), and stiff sunflower (Helianthus rigidus (Cass.) Desf.). Goosefoot and horseweed densities were greater on infested sites $(P<0.05)$ only during 1985 and 1986. Density of stiff sunflower, however, was consistently greater $(P<0.05)$ on infested sites during the study, and became the predominant forb on these sites. Other species which increased $(P<0.05)$ in density for at least 1 year on infested sites were yellow wood sorrel (Oxalis stricta L.), prairie wild rose ( Rosa arkansas Porter), and western snowberry. The lack of reduction of densities for forbs or shrubs on infested sites during the study suggest this species of white grub does not feed on forbs or shrubs. Ueckert (1979) made similar conclusions about Phyllophaga crinita (Burm.) infestations in Texas.

White grub infested areas may pose managerial problems by providing suitable sites for the establishment of noxious weeds. Wormwood sage (Artemisia absinthium $\mathrm{L}$.), virtually absent from uninfested sites $\left(<1.0 \%\right.$ frequency and $<0.1 \mathrm{~m}^{-2}$ ), increased in frequency from $9 \%$ in 1985 to $17 \%$ in 1987 . Although frequency decreased in 1988 , in response to drought, density continued to increase to 5.6 plants $\mathrm{m}^{-2}$.

\section{Conclusions}

More than 3 years may be necessary for vegetation to completely recover from severe white grub infestations in northern mixedgrass prairie. Three years after infestations were noticed, grami- noids on infested sites were not as productive as on uninfested sites. Infested sites are presently dominated by forbs, with noxious weeds becoming increasingly abundant. Management techniques such as the use of herbicides may be necessary to enhance the recovery of grasses and retard or eliminate the establishment of noxious weeds.

\section{Literature Cited}

Anon. 1959. Control of white grubs. USDA Farmers Bull. 1798.

Graber, L.F., C.L. Fluke, and S.T. Dexter. 1931. Insect injury of blue grass in relation to the environment. Ecology 12:547-566.

Hewitt, G.B., W.W. Huddleston, R.J. Lavigne, D.N. Ueckert, and J.G. Watts. 1974. Rangeland entomology. Range Sci. Ser. No. 2. Soc. Range Manage. Denver, Colo.

Kirby, D.R., G.M. Sturn, and T.A. Ransom-Nelson. 1988. Effects of grazing on western snowberry communities in North Dakota. Prairie Natur. 20:161-169.

Kuchler, A.W. 1964. Potential natural vegetation of the conterminous United States. Amer. Geo. Soc. Spec. Pub. 36.

Lura, C.L. 1985. Range plant communities of the Central Grasslands Research Station. Ph.D. Thesis. North Dakota State Univ. Univ. Microfilms. Ann Arbor, Mich. (Diss. Abstr. AAD85-25656).

Richter, P.0. 1958. Biology of Scarabaeidae. Annu. Rev. Entomol. 3:311-334.

Ueckert, D.N. 1979. Impact of a white grub (Phyllophaga crinita) on a shortgrass community and evaluation of selected rehabilitation practices. J. Range Manage. 32:445-448. 